KATARZYNA BŁAŻEJEWSKA*

Warszawa, Polska

ORCID ID: https://www.orcid.org/oooo-0oo3-2793-3276
Forum Pedagogiczne

$10(2020) 1$

Wpłynęło: 19.12.2019

Zatwierdzono do druku: 18.03.2020

DOI: $10.21697 /$ fp.2020.1.07

\title{
PRACA DOMOWA UCZNIÓW W EDUKACJI WCZESNOSZKOLNEJ
}

Streszczenie: Artykuł traktuje o pracy domowej uczniów w edukacji wczesnoszkolnej. Dokonano przeglądu literatury pedagogicznej dotyczącej pracy domowej, koncentrując się na cechach, funkcjach, celach, rodzajach oraz sposobach jej zadawania. Sformułowanych zostało również kilka wniosków dotyczących zadawania pracy domowej na poziomie edukacji wczesnoszkolnej.

Słowa kluczowe: praca domowa; edukacja; edukacja wczesnoszkolna.

Ostatnie lata przyniosły wiele zmian w systemie polskiej edukacji. Zmieniło się również spojrzenie na funkcjonowanie ucznia w tym systemie. Uczeń stał się podmiotem nauczania. Obecnie coraz częściej poruszany jest temat roli zadawanej uczniowi pracy domowej. Mimo że MEN już w 1992 roku wycofało się z centralnego sterowania szkołami, a szkoły regulują swoje działania za pomocą statutów, to nadal rzadko znajdują się w nich zapisy dotyczące pracy domowej. Coraz więcej rodziców jest przeciwnych zadawaniu dzieciom pracy do domu, często cały proceder nazywany jest wręcz, w ekstremalnych przypadkach, ograniczaniem swobód obywatelskich dziecka. Rodzice uważają, że ich prawa rodzicielskie są również w ten sposób ograniczane - nie mają możliwości spędzania czasu ze swoimi dziećmi w sposób inny niż odrabianie pracy domowej.

W literaturze przedmiotu można wyróżnić dwa podejścia do znaczenia pracy domowej:

1. tradycyjne - uznające pracę domową za bardzo istotny element procesu kształcenia;

2. nowsze (oparte na wynikach najnowszych badań) - podkreślające, że wykonywanie zadań w domu nie ma wpływu na postępy w nauce.

W oparciu o literaturę przedmiotu rozważania w niniejszym artykule skoncentrowano na istocie pracy domowej oraz próbie odpowiedzi na pytania: (1) Jakie

* Mgr Katarzyna Błażejewska, Uniwersytet Kardynała Stefana Wyszyńskiego w Warszawie, Wydział Nauk Pedagogicznych; e-mail: k.blazejewska@uksw.edu.pl. 
problemy dotyczące pracy domowej na poziomie edukacji wczesnoszkolnej są poruszane w literaturze pedagogicznej?; (2) Jakie są argumenty za i przeciw zadawaniu pracy domowej na poziomie edukacji wczesnoszkolnej?; (3) Jakie wnioski wynikają z przeprowadzonych analiz?

\section{Praca domowa, jej cechy i funkcje w świetle literatury klasycznej}

Praca nauczyciela podczas zajęć szkolnych „wymaga [...] uzupełnienia i wzbogacenia przez inne formy. Jedną $\mathrm{z}$ takich form jest praca domowa uczniów; tradycyjny składnik systemu szkolnego" (Okoń 2003, s. 330). Praca domowa to „uzupełnienie i ciąg dalszy pracy lekcyjnej”, który „umożliwia [...] pogłębienie i utrwalenie wiedzy ucznia, [...] wdrożenie go do samodzielności w myśleniu i posługiwaniu się wiedzą, w realizowaniu zadań twórczych" (Okoń 2003, s. 330). Jan Zborowski (1955) zwraca uwagę na znaczenie dydaktyczno-wychowawcze pracy domowej: pozwala utrwalić i uzupełnić materiał, przygotowuje do samokształcenia, rozwija indywidualne zainteresowania, zdolności twórcze, uczy wytrwałości, odwagi, systematyczności. Czesław Kupisiewicz (1980, s. 196) także uznaje ją za „integralną część prowadzonego przez szkołę i na terenie szkoły procesu nauczania-uczenia się”. Renata Reclik (2005, s. 138) przyjmuje, „że praca domowa to zharmonizowane z treściami programowymi oraz odpowiadające indywidualnym możliwościom ucznia i wykonywane przez niego w domu zajęcia szkolne, których celem jest z jednej strony rozszerzanie, pogłębianie i utrwalanie treści programowych, z drugiej zaś rozbudzanie inicjatywy i indywidualnych zainteresowań oraz wdrażanie do samokontroli, samooceny i samokształcenia". Wincenty Okoń (2007) oraz Elżbieta Miodek (1988) podkreślają, że celem pracy domowej jest przede wszystkim przygotowanie do samodzielnego myślenia. Władysław Puślecki (2005a, s. 791) uważa, że celem pracy domowej są „oczekiwane osiągnięcia edukacyjne ucznia, będące rezultatem jej realizacji” i wyróżnia trzy dziedziny charakteryzujące cel pracy domowej:

1. uczuciowo-wolicjonalne - to zespół cech osobowościowych ucznia (motywacja, odpowiedzialność, satysfakcja z wykonanej pracy, systematyczność i obowiązkowość), określających jego podmiotowość, charakteryzujących jego dążenia, stosunek do siebie samego i otaczającego go świata oraz wpływających na skuteczność nauki domowej;

2. instrumentalno-adaptacyjne - charakteryzują ucznia od strony intelektualno-sprawnościowej (wiedza, rozumienie, umiejętności, doświadczenie, nawyki);

3. trangresyjno-emancypacyjne - dające szansę na krytyczne ocenianie i twórcze przekraczanie a nie tylko utrwalanie obowiązujących w programach szkolnych schematów myślenia i działania.

Według Haliny Kozak (1984, s. 26), praca domowa ma trzy podstawowe funkcje: „powtarzanie i utrwalanie wiadomości i umiejętności zdobytych w szkole, 
pogłębianie i rozszerzanie ich oraz praktyczne wykorzystanie zdobytych umiejętności”. Kupisiewicz (1980, s 196), wymienia pięć funkcji pracy domowej:

- „opanowanie w drodze samodzielnej pracy w domu określonych wiadomości, stanowiących podstawę do przerabiania w szkole pod kierunkiem nauczyciela nowych zagadnień [...];

- utrwalenie materiału przerobionego na lekcji;

- zebranie pomocy szkolnych [...];

- ukształtowanie u uczniów określonych umiejętności i nawyków w drodze samodzielnego ćwiczenia;

- rozwijanie samodzielności myślenia i działania przez wykonywanie zindywidualizowanych zadań teoretycznych i praktycznych w zakresie wykraczającym poza materiał programowy danego przedmiotu, ale przystosowanym do możliwości poszczególnych uczniów".

Ryszard Więckowski (1983, s. 164) mówi o czterech podstawowych rodzajach pracy domowej w klasach młodszych:

1. „gromadzenie materiałów niezbędnych do pracy szkolnej;

2. prowadzenie obserwacji i eksperymentów,

3. ćwiczenia utrwalające materiał opracowany w toku nauki szkolnej,

4. ćwiczenia związane z kształtowaniem nawyków samodzielnej pracy umysłowej w warunkach domowych".

Józefa Bałachowicz (2006) wskazuje na upodmiotowienia szkolnego uczenia się i konstruktywnego nauczania. Programy nauczania powinny sięgać do prywatnej wiedzy dziecka, osobistych kompetencji i potencjału w tworzeniu integracji z kulturą, pobudzać aktywność ucznia Według autorki, „pedagogika wczesnoszkolna, a następnie praktyka pedagogiczna powinny podjąć głębiej zadania wynikające z paradygmatu «kształcenia dla rozwoju». Chodziłoby o rozwijanie kompetencji związanych z przygotowaniem do całożyciowego uczenia się" (2006, s. 14). W związku z bardzo szybkim rozwojem cywilizacji szkoła musi też podjąć problematykę „rozwoju małego człowieka w kontekście ograniczania relacji bezpośrednich z drugim człowiekiem na rzecz relacji pośrednich, za pomocą środków technicznych" (Bałachowicz 2006, s. 15).

Wraz z postępem i zmianami cywilizacyjnymi zmienia się szkoła i jej podejście do różnych kwestii, w tym pracy domowej. Barbara Dudel (2007, s. 157) podkreśla, że okres edukacji wczesnoszkolnej to okres, „w którym samodzielna działalność ucznia powinna kształtować poczucie radości z uczenia się, satysfakcji z samodzielnego dochodzenia do rozwiązania, oczekiwanego efektu, budzić wiarę we własne siły. Ważne jest, aby dziecko opanowało nawyk samodzielnej pracy, podstawowe umiejętności uczenia się, korzystania z różnych źródeł wiedzy”.

Merrill Harmin (2005) zaleca przy zadawaniu pracy domowej, aby dać uczniom możliwość wyboru: liczby zadań, rodzaju materiału do opanowania, prac wymagających różnej ilości czasu na ich wykonanie. Zaleca też pobudzanie uczniów do samodzielnego formułowania zadań. Według autora przyniesie to długofalowe 
korzyści, m.in. poczucie odpowiedzialności za swoje decyzje. Proponuje sprawdzanie prac domowych w parach lub większych grupach, zachęca do rozmowy z uczniami i do zadawania zadań zupełnie innych od tych wykonywanych na lekcji.

Anna Kołodziej i Bernadeta Niesporek-Szamburska (2009, s. 5) zwracają uwagę na fakt, że „uczeń poznaje rzeczywistość przede wszystkim poza lekcją, klasą, szkołą". W związku z tym, jeśli praca domowa jest odpowiednio zaplanowana, to przygotowuje do samokształcenia. Według autorek praca domowa powinna spełniać następujące kryteria:

- być zaplanowana;

- mieć określony cel (najlepiej ustalony z uczniami, wpływa wtedy na motywację wewnętrzną);

- łączyć różne zadania;

- $\quad$ wpływać na udoskonalenie lekcji (podczas planowania);

- być zindywidualizowana;

- dawać możliwość wyboru zadań, aktywności twórczej oraz nauczenia się czegoś nowego;

- opierać się na określonych zasadach;

- być wyjaśniona, sprawdzona i zrecenzowana (Kołodziej, NiesporekSzamburska 2009).

Irena Adamek (1997) oraz Krystyna Duraj-Nowakowa (1998), omawiając opisane $\mathrm{w}$ literaturze przedmiotu zasady zadawania pracy domowej, zwracają uwagę na fakt, że może być ona zadana na każdym etapie lekcji.

\section{Czy należy zadawać pracę domową?}

Alphie Kohn (2018) krytykuje powszechne podejście do pracy domowej. Wysuwa argumenty dotyczące stresu, jakim jest praca domowa dla rodziców i dla dzieci, podkreśla znaczenie konfliktów rodzinnych powstających przy jej odrabianiu oraz brak czasu na inne zajęcia. Zwraca uwagę na mniejsze zainteresowanie nauką w przypadku stosowania prac domowych. Powołuje się na badania, które wykazały brak wpływu pracy domowej na lepsze wyniki w nauce. Obala pogląd dotyczący wpływu pracy domowej na rozwijanie w uczniach umiejętności zarządzania czasem i odpowiedzialności - twierdząc, że zależy to od wieku i osobowości dzieci. Uważa, że wykonywanie pracy domowej samo w sobie nie nauczy dzieci uczyć się, tylko odrabiać pracę domową (nazywa to błędnym kołem). Zauważa niebezpieczeństwo związane z samodyscypliną - według niego może ona skutkować pracoholizmem A. Kohn (2018) twierdzi, że powszechne jest ignorowanie dowodów na brak skuteczności zadań domowych, często nawet wysuwa się wnioski sprzeczne z wynikami. Ale czy rzeczywiście A. Kohn jest przeciwnikiem zadawania pracy domowej? Uważa, że praca domowa powinna być zadawana tylko wtedy, gdy ma szansę być wartościowa i korzystna dla większości uczniów. Zadań powinno być mało, ale wysokiej jakości. Proponuje zadania takie jak: rozmowa z rodzicami, eksperymenty, czynności 
wykonywane wspólnie z rodziną (gry, krzyżówki, czytanie na głos). Twierdzi także, że uczniowie powinni mieć wpływ na rodzaj i ilość pracy domowej. Powinni móc decydować o czasie oddania pracy, wyborze tematu. Najlepiej, żeby mieli szansę wypowiedzieć się, czy w ogóle robienie danego zadania wydaje im się sensowne i korzystne. Według niego praca domowa powinna być kreatywna i samodzielnie przygotowana przez nauczyciela, co sprzyja indywidualizacji. Zachęca do włączenia rodziców w proces zadawania prac domowych, kładzie nacisk na wspólne podejmowanie decyzji. Kwestionuje jednak wartość kontrolowania i oceniania tego, co uczniowie zrobili - skupić należy się na wspólnym wyjaśnianiu i przyglądaniu się temu, co uczniowie przygotowali, a nie na karaniu za błędy (jest ono niedopuszczalne). Autor zwraca uwagę na to, że za nauczanie odpowiedzialni są nauczyciele w szkole, a nie rodzice w domu. Według niego dzieci, które nie spędziły długiego czasu na wykonywaniu pracy domowej, będą bardziej wypoczęte i będą lepiej pracować następnego dnia na lekcjach (Kohn 2018).

Jesper Juul (2014) przytacza wnioski z badań przeprowadzonych w szkołach duńskich i stwierdza, że „odrabianie zadań w domu jest kontrproduktywne i hamuje postępy w nauce, zamiast je wspierać" (Juul 2014, s. 48). W związku z oporem szkół do rezygnacji z prac domowych autor zwraca uwagę na konieczność przekazania odpowiedzialności za prace domowe uczniom.

John Hattie (2005) dokonał syntezy pięciu metaanaliz dotyczących pracy domowej. Jego zdaniem zebrane dane są jednoznaczne. Wynika z nich, iż „wpływ zadawania i odrabiania prac domowych jest niewielki, a w przypadku szkół podstawowych zupełnie nikły" (Hattie 2015, s. 36). Autor uważa, że ten wniosek powinien skłonić nauczycieli do zmiany podejścia do prac domowych.

\section{Praca domowa w edukacji wczesnoszkolnej}

Tematyce pracy domowej na poziomie edukacji wczesnoszkolnej swoje prace poświęcili: H. Kozak (1984), I. Adamek (1997), B. Dudel (2007), K. Duraj-Nowakowa (1998), ale temat rozpatrują dogłębnie przede wszystkim W. Puślecki (2005b) i R. Reclik (2005).

W. Puślecki (2005b) na podstawie badań własnych zwraca głównie uwagę na fakt, że zadawane prace domowe nie mają charakteru zintegrowanego, lecz przedmiotowy. Najczęściej nauczyciele zadają prace z edukacji polonistycznej (49,7 proc.) i matematycznej (17,3 proc.). Istotną rolę pełni systematyczna kontrola odrabianych prac domowych, ich omówienie oraz poprawa błędów umożliwiająca usuwanie braków na bieżąco. Sprawdzając ją regularnie, wdrażamy uczniów do systematyczności. B. Dudel (2007) podkreśla, że należy uwzględniać samodzielność ucznia i jego pomysłowość.

Często nauczyciele zadają uczniom do domu naukę czytania tekstu. Budzi to sprzeciw rodziców, którzy uważają, że szkoła przenosi obowiązek nauczania na nich. Należy jednak pamiętać, że czytanie i pisanie to najważniejsze umiejętności 
nabywane w klasach I-III. Bez systematycznej pracy, ćwiczenia i utrwalania, także w domu, uczeń może mieć duże problemy w ich opanowaniu. Regularne czytanie pozwala nauczyć się czytać poprawnie, płynnie, biegle i wyraziście. W klasie liczącej 20-25 uczniów nauczyciel nie jest w stanie poświęcić każdemu uczniowi tyle czasu, ile potrzebuje on na głośne czytanie. Codzienne natomiast, trwające kilka minut, wspólne z rodzicami głośne czytanie może stać się miłym zwyczajem oraz momentem na zadawanie pytań i wymianę myśli dotyczących czytanego tekstu. Te rozważania potwierdzają wyniki badań - 19,3 proc. sposobów sprawdzania prac domowych stanowi czytanie tekstu zadanego do domu (Puślecki 2005b). Pozostałe sposoby sprawdzania prac domowych (m.in. odpytywanie, zbieranie prac) są zdecydowanie mniej popularne.

Nauczyciele stosują pięć sposobów zadawania pracy domowej:

1. narzucanie;

2. oferowanie wyboru;

3. wspólne ustalanie;

4. inicjatywę oduczniowską;

5. propozycje fakultatywne.

Niestety, w 85,1 proc. przypadków nauczyciele narzucają pracę domową, czyli uczniowie nie mają wpływu na proces dydaktyczno-wychowawczy (Puślecki 2005b).

W. Puślecki (2005b) zwraca również uwagę na to, że zadania, które nauczyciele zadają dzieciom, mogą być:

1. poprawne - zawsze trzeba określić cel pracy domowej, uchwycić jej związek z lekcją odbytą lub przyszłą. Należy wziąć pod uwagę poziom rozwoju uczniów i ich umiejętności w celu indywidualizowania prac domowych, które pozwolą osiągnąć sukces każdemu uczniowi, pobudzą go do zdobywania wiedzy;

2. $\quad$ ogólnikowe - mało konkretne;

3. zadane ad hoc - praca domowa nie może mieć przypadkowego charakteru. Musi być zaplanowana i przemyślana. Nie można zadawać kolejnego zadania (które zazwyczaj jest trudniejsze od poprzednich) lub tego, czego nie zdążyliśmy zrobić na lekcji;

4. zadania priorytetowo-tradycyjne - mające stałą formę;

5. niby zadania domowe - prośba o przyniesienie określonych rzeczy lub wykonanie czynności.

Z badań W. Puśleckiego (2005b) wynika, że najczęściej nauczyciele zadają zadania poprawne $(42,8$ proc.) oraz priorytetowo-tradycyjne ( 28,7 proc.). Niestety, aż 9,2 proc. zadań jest zadawanych ad hoc. Także badania Bogumiły Dudzińskiej (2003) wskazują na niepokojący fakt zadawania do domu ćwiczeń, których uczniowie nie zdążyli wykonać na lekcji.

W. Puślecki (2005b) określił typy zadań zależne od ich celów:

1. utrwalające nabytą wiedzę; 
2. rozwijające umiejętności i nawyki („żadnej umiejętności [...] nie osiągnie się bez systematycznych i rozłożonych w czasie ćwiczeń”) (2005b, s. 44);

3. transgresyjne;

4. praktyczne;

5. gromadzenie odpowiednich przedmiotów przydatnych w czasie zajęć szkolnych.

Badania B. Dudzińskiej (2003) wykazały, że zadawane prace domowe najczęściej służą ćwiczeniu sprawności, narzucają sposób pracy, lecz nie uczą samodzielności. Także według badań W. Puśleckiego (2005b), 61,6 proc. prac domowych koncentruje się wokół rozwijania umiejętności i nawyków - czytania, pisania, rysowania i obliczania. Praktyka szkolna pokazuje, że spora część dzieci ma niską sprawność manualną, zaburzenia grafomotoryczne. Bez ćwiczeń nie nauczą się pisać, nie nauczą ręki prawidłowego chwytu, nie będą mogły pisać dłużej bez zmęczenia czy nawet bólu ręki. Litery nie będą kształtne, prawidłowo połączone i jednolicie pochylone. Pismo nie będzie czytelne i estetyczne. Ćwiczeniami doskonalącymi sprawność manualną są: obrysowywanie, rysowanie po śladzie, według wzoru i samodzielnie, łączenie kropek, prowadzenie linii, kreskowanie - wszystko to, co jest wstępem do nauki pisania. Na początku klasy I zadaje się prace domowe usprawniające te umiejętności. Poza sprawnością w pisaniu, ćwiczenie pisania liter utrwala w pamięci wygląd poszczególnych liter pisanych. Czytanie jest podstawową umiejętnością zdobywaną przez uczniów w klasach I-III i może decydować o ich przyszłych osiągnięciach i sukcesach szkolnych. Tylko regularne ćwiczenie pozwala nauczyć uczniów czytania poprawnego, płynnego, biegłego i wyrazistego. To wskazuje na konieczność zadawania zadań rozwijających umiejętności i nawyki.

Według badań R. Reclik (2005), 90,1 proc. prac domowych służy powtórzeniu i utrwaleniu wiadomości. Takie zadania są oczywiście konieczne na tym etapie nauczania. Nauczyciele dużą wagę przywiązują do zadawania zadań rozwijających samodzielność i twórczość myślenia (drugie miejsce), najmniejszą do obserwacji i eksperymentów (Reclik, 2005). W. Puślecki (2005b) zauważa, iż mimo nacisku kładzionego przez programy nauczania na twórczość i kreatywność uczniów oraz na doświadczanie, takie zadania stanowiły tylko 9,2 proc. wszystkich zadań domowych. Rozbieżność wyników wynika zapewne z faktu, że zespół W. Puśleckiego (2005b) obserwował zajęcia i oceniał sytuacje zaistniałe, R. Reclik (2005) natomiast badała opinie nauczycieli.

Wnioski wynikające z badań W. Puśleckiego (2005b) nie są zbyt optymistyczne w większości przypadków praca jest narzucana przez nauczyciela, 28,5 proc. zadań jest niezaplanowanych lub nic niewnoszących do procesu nauczania, a większość z nich koncentruje się wokół utrwalania wiedzy i rozwijania umiejętności. Brakuje zadań praktycznych i twórczych. Założenia kształcenia zintegrowanego są jasne proces edukacyjny należy traktować całościowo. Dotyczy to wszystkich elementów wchodzących w skład tego procesu, także prac domowych. Wyniki badań wskazują, że jedynie 18,8 proc. prac domowych było bezpośrednio powiązanych $\mathrm{z}$ tematem 
dnia, pośrednio 40,3 proc. (Puślecki 2005b). R. Reclik (2005) zwraca również uwagę na przeważający przedmiotowy charakter pracy domowej - co dziesiąty nauczyciel integruje różne treści, najczęściej język polski z przyrodą lub muzyką.

\section{Wnioski końcowe i konkluzje pedagogiczne}

Mimo dosyć jednoznacznych wniosków płynących z najnowszych badań dotyczących pracy domowej żaden autor nie mówi wprost o potrzebie zaprzestania zadawania prac domowych uczniom na etapie edukacji wczesnoszkolnej. Wyniki wcześniejszych badań (Puślecki 2005b; Reclik 2005) wskazują na potrzebę zadawania prac domowych. Myślę, że właśnie ze względu na niezmieniony od lat, mimo reform, charakter prac domowych, powinniśmy skoncentrować się przede wszystkim na pytaniach, jakie zadania należy proponować do realizacji w domu uczniom na poziomie edukacji wczesnoszkolnej i w jaki sposób powinny być one realizowane, aby praca domowa ujmowana była holistycznie i spełniała swoją podstawową funkcję - przygotowywała do samokształcenia. W literaturze przedmiotu brakuje podpowiedzi i konkretnych rozwiązań dla nauczycieli. Ogólne wytyczne można znaleźć w literaturze klasycznej. Pozycje z przełomu wieków, odnoszące się do zmiany sposobu nauczania i wprowadzenia programu zintegrowanego, pomijają ten aspekt lub powtarzają metody za klasykami. Przewodniki metodyczne proponują pewne rozwiązania, jednak nadal większość proponowanych zadań ma charakter przedmiotowy. Mimo badań ogólnych, wskazujących na niewielki wpływ zadawania prac domowych na efekty nauczania w szkole podstawowej, brakuje konkretnych propozycji, czym je zastąpić, w przypadku chociażby potrzeby wyćwiczenia podstawowych umiejętności, takich jak czytanie i pisanie. Ponadto, jak zwraca uwagę B. Dudel (2007), ten etap, w szczególności okres klasy III, charakteryzuje zaangażowanie i obowiązkowość, które warto wykorzystać w procesie nauczania, w tym przy zadawaniu prac domowych.

Przyjmując za podstawę badania przeprowadzone przez W. Puśleckiego', $\mathrm{w}$ połączeniu $\mathrm{z}$ teorią zawartą $\mathrm{w}$ literaturze dydaktycznej i pedagogicznej oraz z doświadczeniem własnym, można sformułować kilka wniosków dotyczących zadawania pracy domowej na poziomie edukacji wczesnoszkolnej.

Nauczyciele powinni traktować proces edukacyjny holistycznie, a co za tym idzie, praca domowa powinna być zgodna $z$ celem lub celami oraz tematem dnia, winna służyć zrozumieniu materiału, utrwaleniu wiedzy, szczególnie tej, którą uczniowie będą umieli wykorzystać w różnych sytuacjach i dzięki której będą umieli rozwiązywać różnorakie problemy. Powinna doskonalić umiejętności, rozwijać zainteresowania, pomysłowość oraz pozytywny stosunek do pracy, kształtować umiejętność samodzielnego, krytycznego myślenia, uczenia się, uczyć

1 W. Puślecki badał rzeczywistość szkolną na początku XXI wieku. Autor wziął pod uwagę zmiany, jakie dokonały się w edukacji, zmiany programowe oraz ówczesną rzeczywistość szkolną. 
samodoskonalenia, samodyscypliny, samokontroli, samooceny, lepszej organizacji czasu, odpowiedzialności, rozwijać motywację do uczenia się, wiarę we własne siły, zainteresowania oraz stwarzać możliwość wszechstronnego rozwoju, przede wszystkim zdolności twórczych. Obok zadań koniecznych, utrwalających umiejętności twórcze, rozwijających kreatywność, myślenie dywergencyjne, samodzielność w myśleniu, uwzględniających zainteresowania dzieci, istnieją również zadania poświęcone zagadnieniom, których uczniowie nie opanują, bez ich ćwiczenia, jak czytanie i pisanie - najważniejsze umiejętności nabywane w klasach I-III. Powyżej opisane cele będą spełnione, jeśli praca zostanie zintegrowana z edukacją szkolną, przemyślana i zaplanowana. Lekcja i praca domowa „stanowią organicznie powiązaną całość procesu kształcenia” (Kujawiński 1990, s. 13). Zadany temat powinien być atrakcyjny i winien zawierać elementy twórcze. Dzieci w wieku 7-10 lat zapamiętują to, co je zainteresuje. Nauka powinna być dla nich pewnego rodzaju przygodą.

Zawsze trzeba uwzględniać indywidualność i niepowtarzalność uczniów, ich potrzeby i możliwości, oraz indywidualizować pracę domową. Można zaproponować zadania na dwóch-trzech poziomach. Dzieci powinny mieć możliwość wyboru metod i technik pracy. Praca domowa nie powinna być zadawana za karę. Ważne jest również wytłumaczenie zadanej dzieciom do domu pracy. Polecenia powinny być jasne, zrozumiałe dla wszystkich uczniów. Co ważne, zadania powinny być łatwiejsze od tych wykonywanych na lekcji. Praca domowa będzie pogłębiała wiedzę, rozwijała umiejętności oraz przygotowywała do samokształcenia, jeśli zostanie dopasowana przede wszystkim pod względem ilości (zadając dzieciom w klasie I do napisania kilka linijek nowo poznanej litery, nie należy zadawać tyle samo linijek nowo poznanej cyfry) oraz treści. W klasie I powinna zajmować do 30 minut, w klasie III - do godziny. Zawsze też należy sprawdzić pracę domową - nie po to, aby karać za błędy, lecz żeby poznać możliwości i umiejętności dziecka. Jeśli praca będzie oceniona prawidłowo, z uwzględnieniem wszystkich funkcji oceny opisowej, to uczeń i jego rodzice będą wiedzieli, co dziecko już umie, a nad czym powinno jeszcze popracować.

Być może obecny sprzeciw wobec prac domowych wiąże się ze sposobem ich zadawania. Biorąc za podstawę osobiste doświadczenia w tym zakresie, uważam, że istnieje potrzeba proponowania uczniom twórczej pracy domowej. Pracując z dziećmi, zawsze się starałam, aby praca domowa była jednocześnie celowa i atrakcyjna dla dzieci. Zazwyczaj były to krótkie, interesujące ćwiczenia, często w innej formie niż podczas zajęć lekcyjnych. Realizowały jednak cel, który mieli osiągnąć uczniowie. Dostosowywałam ją do zainteresowań klasy - gdy uczniowie lubili kolorować, częściej zadawałam kolorowanki z obrazkiem związanym z tematem dnia, z działaniami lub trudnościami ortograficznymi. Grupie lubiącej gry planszowe proponowałam układanie gier na lekcjach, a w domu - wymyślanie dalszych losów bohaterów (gry, opowiadania) lub strategii. Uczniowie klasy III przygotowywali prezentacje, albumy - pisali samodzielnie, sami wykonywali ilustracje - a niezbędna pomoc rodziców odbierana była jako możliwość wspólnego poszukiwania informacji i ciekawostek na dany temat. W domu dzieci hodowały 
pleśń i opisywały zaobserwowane zmiany. Dokonywały codziennych obserwacji pogody, zmian temperatury, ciśnienia (na barometrach, które konstruowaliśmy w szkole). Pracę domową omawialiśmy w miłej atmosferze, bez karania za błędy.

Istotną kwestią jest „wykorzystywanie na lekcjach [...] rezultatów pracy domowej oraz wykorzystywanie efektów lekcji w pracy domowej" (Kujawiński 1990, s. 13). Jeśli zadajemy uczniom do wykonania jakiś projekt, doświadczenie - pozwólmy pochwalić się dzieciom efektami, spostrzeżeniami przed całą klasą, a wiedzę praktyczną, którą uzyskały, wykorzystujmy przy każdej okazji. Pozwólmy porównywać im swoje obserwacje. Zadawajmy takie prace domowe, aby dziecko nie odczuwało bezcelowości działań.

W. Puślecki (2005b) podkreśla znaczenie świadomości rodziców w odniesieniu do roli, jaką odgrywa zadana dzieciom praca domowa. Powinni zorganizować dziecku warunki do pracy - odpowiednie miejsce w domu oraz czas. Optymistyczne są wyniki badań mówiące, że 68,1 proc. badanych ma swój pokój lub wydzielony kącik do nauki. Ogromny wpływ na uczenie się przez dziecko samodzielności ma atmosfera pracy (powaga, niezakłócanie ciszy) i zainteresowanie rodziców nauką.

Według badań prowadzonych w 2004 roku przez Annę Winiarczyk (20072008), rodzice uważają, że ich pomoc w odrabianiu lekcji jest niezbędna głównie ze względu na niedostateczne wytłumaczenie pracy domowej przez nauczyciela. Kwestia ta jest też poruszana przez B. Dudzińską (2003), która zwraca uwagę na pośpiech podczas zadawania pracy domowej i niewyjaśnianie przez nauczycieli proponowanych zadań. Konieczne jest więc wytłumaczenie rodzicom, że powinni naprowadzać, zadawać pytania pomocnicze, a nie tylko wykonywać zadania za dzieci. Utrudnieniem $\mathrm{w}$ procesie nabywania przez uczniów przede wszystkim umiejętności czytania i pisania może być także pogląd niektórych rodziców, że codzienne odrabianie pracy domowej powoduje brak czasu wolnego dla rodziny, a w domu dzieci nie powinny pracować, tylko odpoczywać.

Szkoła i dom powinny się uzupełniać. Rodzice powinni interesować się zarówno sukcesami, jak i porażkami swoich pociech. Dzięki zainteresowaniu rodziców dzieci podtrzymują zapał do nauki, uczą się obowiązkowości i pilności. W obecnych czasach często tylko dzięki pracy domowej i poświęceniu jej uwagi rodzice wiedzą, czego dzieci obecnie się uczą. Czytając wypowiedzi rodziców, niechętnie patrzących na zadawanie pracy domowej swoim dzieciom, można zauważyć, że najczęściej podają oni argumenty mówiące o antypatii uczniów wobec pracy domowej. Dawno już potwierdzono, że najbardziej skuteczna jest nauka oparta na wewnętrznej motywacji, gdy dzieci są nią autentycznie zainteresowane, a nie wtedy, gdy każdego dnia są zmuszane do odrabiania pracy domowej, a za niewykonanie jej są karane. Jak wynika z badań (Puślecki, 2005b), u 87,5 proc. uczniów motywacja jest zewnętrzna (polecenie nauczyciela), 68,7 proc. - oczekuje uznania. Niestety, tylko 36,9 proc. badanych wskazało na chęć lepszego opanowania jakiegoś zagadnienia. Ciekawy jest fakt, że aż 31,1 proc. uczniów wskazało na zamiłowanie do odrabiania prac domowych! Wyniki te wskazują na to, że uczniowie raczej lubią prace domowe, 
mimo iż zazwyczaj dominującym czynnikiem jest motywacja zewnętrzna, często połączona $\mathrm{z}$ innymi argumentami.

Moim założeniem było omówienie istoty pracy domowej, jej cech, funkcji i celów na podstawie literatury przedmiotu. Nie należy zapominać też o nauczycielach, którzy są jednym z trzech ogniw edukacji, obok uczniów i ich rodziców. Ogniwem, które ma właściwie decydujący głos w sprawie zadawania pracy domowej. To od nich zależy, czy praca domowa będzie zadawana i jaka ona będzie. Uważam, że temat jest bardzo obszerny i wymaga pogłębienia. W świetle najnowszych badań i odkryć naukowych podejście do edukacji, w tym do tematu pracy domowej, powinno się zmienić. Jak bowiem wskazują wyniki badań R. Reclik (2005), charakter pracy domowej nie zmienił się od kilkudziesięciu lat.

\section{Bibliografia}

Adamek I. (1997). Podstawy edukacji wczesnoszkolnej. Kraków: Impuls.

Bałachowicz J. (2006). Wczesna edukacja dziecka - problem teoretyczne i praktyczne. Rola wczesnej edukacji w rozwoju człowieka. W: Bałachowicz J., Kowalska A. (red.). Wczesna edukacja dziecka. Stan obecny-perspektywy-potrzeby. Warszawa: Wydawnictwo Wyższej Szkoły Pedagogicznej TWP.

Cooper H. Synthesis of Research on Homework, dostępny na: https:// s3.amazonaws.com/academia.edu.documents/40892227/el198911_cooper. pdf?response-content-disposition=inline\%3B\%2ofilename\%3Dinvitatie_povesti.pdf\&X-Amz-Algorithm=AWS4-HMAC-SHA 256\&X-Amz-Credentia l=AKIAIWOWYYGZ2Y53UL3A\%2F2O191210\%2Fus-east-1\%2Fs3\%2Faws4_ request $\& X-A m z-D a t e=20191210$ To $93518 Z \& X-A m z-E x p i r e s=3600 \& X-$ -Amz-SignedHeaders=host $\& X-A m z-$ Signature $=$ of $3331 \mathrm{e} 884 \mathrm{~d} 28 \mathrm{~b} 43 \mathrm{~d} 61 \mathrm{acb} 5 \mathrm{f} 1 \mathrm{ob}-$ b25a6eebbd1421fd3c266e8c267d2b54b1475 (otwarty: 27.06.2019).

Denek K. (2001). Pierwszy etap reformowania systemu edukacji w Polsce. W: Moroz H. (red.). Edukacja w reformowanej szkole. Kraków: Impuls.

Drozd E. (1999). Zadawanie do domu. „Edukacja i Dialog”, nr 9, s. 58-63.

Dudel B. (2007). Praca domowa - krok do samokształcenia w klasie III. W: Piwowarski R. (red.). Dziecko sukcesy i porażki. Warszawa: Instytut Badań Edukacyjnych.

Dudzińska B. (2003) Praca domowa w procesie edukacji. „Problemy Opiekuńczo-Wychowawcze", nr 10, s. 37-40.

Duraj-Nowakowa K. (1998). Integrowanie edukacji wczesnoszkolnej. Modernizacja teorii i praktyki. Kraków: Impuls

Harmin M. (2005). Duch klasy. Jak motywować uczniów do nauki? Warszawa: CEO Civitas.

Hattie J. (2015). Widoczne uczenie się nauczycieli. Jak maksymalizować siłę oddziaływania na uczenie się. Warszawa: Biblioteka Szkoły Uczącej się. Juul J. (2014). Kryzys szkoły. Podkowa Leśna: Wydawnictwo MiND. 
Kohn A. (2018). Mit pracy domowej. Podkowa Leśna: Wydawnictwo MiND.

Kołodziej A., Niesporek-Szamburska B. (2009). Konteksty i uwarunkowania zadań domowych, cz. II cyklu: O pracach domowych z języka polskiego prawie wszystko. Kielce: Wydawnictwo Pedagogiczne ZNP.

Kozak H. (1984). Organizacja pracy domowej uczniów klas początkowych. Warszawa: Instytut Wydawniczy Związków Zawodowych.

Kujawiński J. (1990). O nowa jakość pracy lekcyjno-domowej. „Życie Szkoły”, nr 1, s. $13-20$.

Kupisiewicz C. (1980). Podstawy dydaktyki ogólnej. Warszawa: PWN.

Kupisiewicz C., Kupisiewicz M. (2009). Słownik pedagogiczny. Warszawa: PWN.

Miodek E. (1988). O problemach pracy domowej ucznia klas I-III. „Chowanna”, nr 1, s. 48-54.

Niemierko B (2014). Uczeń odrabia pracę domową. „Nowa Szkoła”, nr 2, s. 29-30.

Nowik J. (2013). Kształcenie matematyczne w edukacji wczesnoszkolnej. Opole: Wydawnictwo NOWIK.

Okoń W. (2007). Nowy słownik pedagogiczny. Warszawa: PWN.

Okoń W. (2003). Wprowadzenie do dydaktyki ogólnej. Warszawa: Żak.

Puślecki W. (2005a). Praca domowa ucznia. W: Pilch T. (red.). Encyklopedia pedagogiczna XXI wieku, t. IV. Warszawa: Wydawnictwo Żak.

Puślecki W. (2005b). Praca domowa najmłodszych uczniów. Kraków: Impuls.

Więckowski R. (1983). Nauka domowa dziecka w młodszym wieku szkolnym. „Życie szkoły", nr 3.

Reclik R. (2005). Rola i miejsce pracy domowej w kształceniu zintegrowanym. W: Ratajek Z. (red.). Uczeń we współczesnej szkole. Problemy reformy edukacji wczesnoszkolnej. Kielce: Wydawnictwo Akademii Świętokrzyskiej.

Reclik R. (2007). Praca domowa uczniów w młodszym wieku szkolnym między teoria a praktyka. W: Siwek H. (red.). Efektywność kształcenia zintegrowanego. Implikacje dla teorii i praktyki. Katowice-Warszawa: Wydawnictwo Wyższej Szkoły Pedagogicznej TWP.

Winiarczyk A. (2007-2008). Praca domowa uczniów klas początkowych w opinii rodziców. „Nauczanie początkowe”, nr 2, s. 60-67.

Wujek T. (1969). Praca domowa i czynny wypoczynek ucznia. Warszawa: PZWS.

Zborowski J. (1955). Praca domowa ucznia szkoły podstawowej. Warszawa: PZWS.

\title{
STUDENTS' HOMEWORK IN EARLY SCHOOL EDUCATION
}

\begin{abstract}
The article is about homework in early childhood education. A review of the pedagogical literature on homework has been carried out, focusing on features, functions, objectives, types and ways of giving it. Several conclusions have also been formulated, regarding homework at the early childhood education level.
\end{abstract}

Keywords: objectives; functions and features of homework; early school education. 